\title{
ВИКОРИСТАННЯ РАДЯНСЬКИМИ СИЛОВИМИ ОРГАНАМИ АГЕНТУРНО-ІНФОРМАЦІЙНОЇ МЕРЕЖІ У БОРОТЬБІ ІЗ ПІДПІЛЛЯМ У КАРПАТСЬКОМУ КРАЇ ОУН (1945 - 1954)
}

\begin{abstract}
У статті на основі невідомих і маловідомих документів розкривається один із методів боротьби радянських репресивно-каральних органів проти украӥнського визвольного руху - використання агентурно-інформаційної мережі. Встановлені основні приниипи залучення включення до агентури. Виявлено, щяо їхніми головними завданнями стали не лише фізичне знищення чи захоплення підпільників і повстанці, їхніх ліній зв'язку, кореспондениії, криївк, але й дискредитація цџілого руху в очах місцевого населення. Вперше наводяться кількісні показники агентурно-інформативного апарату.
\end{abstract}

Ключові слова: агентурно-інформачійна мережа, украйнський визвольний рух, Карпатський край ОУН. Jim. 80 .

Vasyl ILNYTSKYI, PhD hab (History), Associate Professor of Ukraine's New and Modern History Department Drohobych Ivan Franko State Pedagogical University (Ukraine,Drohobych)vilnickiy@gmail.com

\section{THE USE BY THE STATE FORCE ORGANS OF THE INTELLIGENCE AND INFORMATION NETWORK DURING THE STRUGGLE AGAINST THE UNDERGROUND IN THE CARPATHIAN AREA OF THE OUN (1945 - 1954)}

Along with operations conducted by the military and extraordinary committee members aimed to do away with the OUN, the state punitive organs began the work of intelligence agents directed to create of an information agents apparatus, as well as to form special fighting groups. Special agents fulfilled also other functions, disrupting the unity of the nationalist organizations from inside was among them. It is noteworthy, that it was that method of fighting agents which was used most frequently.

In order to increase ability to work the punitive organs conducted special training of intelligence agents, whose principal task was to supply qualified cadres. The Soviet repressive-punitive system used to enact various categories of agents depending on their functional duties (agent-fighter, external agent, internal agent, twin agent, agent-signaller, route agent, agent-propagandist, agent-raider, informer, agent "empowered to act for somebody», etc.

Capable for work and valuable agents were acquired by means of secret capture of the OUN members during operations and local recruiting. Besides, agents were enlisted from-among members of former clandestine groups and orderlies of the OUN with legal residence, who worked at factories and other industrial establishments. The recruiting process took a long time and consisted of several stages. The strength of Soviet secret service was considerable. Against every OUN's unit (whether sectional, district, supra-district, regional, or areal) and every UPA department the intelligence cooked up charges, and later, after the necessary persons were liquidated, the cases were closed lest new or renewed units were found out for what reason new cases were opened (predominantly, under corresponding other titles). However, the expectations of the Soviet power for quick and complete destruction of the liberation movement failed. Therefore, agent work became distributed in all possible forms. As a rule, in the complex of anti-nationalistic operations to agent training the central place was dedicated. It is remarkable, that the aforementioned fighting means proved very - or even very much - effective.

Key words: intelligence and information network, Ukrainian liberation movement of the OUN Carpathian region.

Ref. 80. 
Василий ИЛЬНИЦКИЙ,

доктор исторических наук,

доиент кафедры новой и новейшей истории Украины

Дрогобычского государственного педагогического

университета имени Ивана Франко

(Украина, Дрогобыч) vilnickiy@gmail.com

\title{
ИСПОЛЬЗОВАНИЕ СОВЕТСКИМИ СИЛОВЫМИ ОРГАНАМИ АГЕНТУРНО-ИНФОРМАЦИОННОЙ СЕТИ В БОРЬБЕ ИЗ ПОДПОЛЬЕМ В КАРПАТСКОМ КРАЕ ОУН (1945 - 1954)
}

\begin{abstract}
В статье на основе неизвестных и малоизвестных документов раскрывается один из методов борьбы советских репрессивно-карательных органов против украинского освободительного движения - использование агентурно-информационной сети. Установлены основные принципь привлечения включения в агентуры. Выявлено, что их главныли задачами стали не только физическое уничтожение или захват подпольщиков и повстанцы, их линий связи, корреспонденции, укрытий, но и дискредитация цчелого движения в глазах местного населения. Впервые приводятся количественные показатели агентурно-информативного annapama.
\end{abstract}

Ключевые слова: агентурно-информационная сеть, украинское освободительное движение, Карпатский край ОУН.

Лит. 80.

Постановка проблеми. Репресивно-каральна система широко використовувала величезну кількість форм і методів у боротьбі із українським визвольним рухом. 3-поміж найбільш ефективних виявилася створена агентурно-інформаційна мережа. Донедавна це питання перебувало під суворим табу. Однак відкриття архівів репресивно-каральних органів дозволяє розкрити це питання.

Аналіз досліджень. Частково питання створення та діяльності агентурно-інформаційного апарату знайшло своє висвітлення в узагальнюючих працях із історії ОУН і УПА. Зокрема, вперше проблеми функціонування агентірної мережі на серйозний науковий рівень підняв Іван Білас $[2 ; 3]$. Своє відображення вказана проблема знайшла у публікації раніше засекречених документів Володимиром Сергійчуком [73; 74; 75]. В подальшому питання використання агентури знайшло своє відображення в узагальнюючих дослідженнях Анатолія Кентія, Юрія Киричука, Анатолія Русначенка, Юрія Шаповала $[65 ; 66 ; 67 ; 72 ; 80]$. Саме тому метою статті є дослідити особливості формування та засади діяльності агентурно-інформаційної мережі у Карпатському краї ОУН (1945 - 1954).

Виклад основного матеріалу. Разом із проведенням військово-чекістських операцій з ліквідації ОУН репресивно-каральні органи розпочали агентурну роботу, яка полягала у створенні агентурно-інформативного апарату, а також формуванні спеціальних агентурно-бойових груп [79, 72]. Агентура виконувала й інші функції, наприклад, розкладання націоналістичних організацій зсередини $[49,90]$. Варто відзначити, що саме агентурний метод боротьби використовувався найчастіше. 3 метою налагодження агентурної роботи і створення «паралельної агентурної мережі» секретні працівники МВС, МДБ і агентура функціонували під виглядом підпілля ОУН. До великих міст західних областей України з 10 липня 1946 р. почали направляти досвідчених оперативників, переводячи їх на становище «негласних працівників». Під безпосереднім керівництвом перших секретарів обкомів КП(б)У їх влаштовували на роботу під виглядом представників різних заготівельних організацій або добровільних товариств, забезпечуючи відповідними документами. До кожного з них прикріплювали 30-40 агентів із прилеглих до міста районів. Такі «паралельні мережі» утворили в кожному місті шести областей західного регіону, куди скерували по одному працівникові [1, 119-120; 2, 278].

3 метою підняття працездатності репресивно-каральні органи проводили спеціальні агентурно-розвідувальні вишколи, головне завдання яких полягало у забезпеченні агентури фаховими силами. Інформацію про них не вдалося виявити у документах спецслужб, натомість у підпіль- 
них матеріалах така міститься. Наприклад, упродовж 2 лютого - 6 березня 1945 р. відбувся агентурний вишкіл у м. Копичинці Тернопільської обл., на якому було 72 учасники, всі чоловіки, за походженням з Львівської, Тернопільської та Станіславської областей. Влітку 1945 р. відбувся агентурно-розвідувальний вишкіл у Гвіздці, біля Коломиї, для підлітків. Курс тривав один тиждень. 323 липня до 10 серпня 1945 р. при Чернівецькому державному університеті працювали курси перепідготовки директорів неповних середніх і середніх шкіл (120 учасників) із західних областей України. До того вони були активними агентами НКВС. Окрім предметів перепідготовки вчителів, викладалися також методи боротьби з ОУН. Підпільники навіть знали прізвища і посади осіб, які викладали [47, 203-204]. Оскільки оунівці у своїй роботі робили акцент на роботі з інтелігенцією (лікарі, педагоги) та іншими прибулими особами зі східних областей України, спецслужби вважали доцільним створити при міністерстві МДБ УРСР оперативну групу, яка мала вербувати і готувати агентуру у вищих і середніх навчальних закладах. Ї̈̈ направляли до західних областей України для введення у підпілля по районах з найбільшою концентрацією та використовувати для перехоплення каналів зв'язку із підпіллям у східних областях України [38, 71-72].

Таким чином, на виховання агентури зверталася особлива увага, зв'язок із нею здійснювався відповідно до складених графіків, наголошувалося на придбанні конспіративних квартир. Акцент робився на розстановці агентури у населених пунктах, у районах промислових і сільськогосподарських об'єктів, пунктах проходження залізничних доріг, ліній зв'язку і маршрутів спецзв'язку $[30,24]$.

Радянська репресивно-каральна система використовувала різноманітні категорії співробітників залежно від їхніх функціональних обов'язків: резидент, агент (агент-бойовик, агент-внутрішник, агент-зовнішник, агент-двійник, агент-зв'язківець, агент-маршрутник, агент-пропагандист, агент-рейдовик), інформатор, «довірена особа». Найважливішою категорією був резидент таємний співробітник, який керував роботою групи агентів чи таємних інформаторів, переважно працював за переконаннями, користувався авторитетом і довірою в репресивно-каральних органах. Йому дозволялося підшуковувати відповідні кандидатури на вербування до агентурної сітки. Там, де працював резидент, агентура ділилася на звена по п'ять-шість осіб у кожному (горизонтальна структура сітки). Другий найбільш структурований елемент - агент - найбільш різновидна форма донощика у всій агентурній сітці, це переважно учасник підпільної організації, який самостійно міг виконувати спеціальні завдання. Вирізнявся він тим, що працював на ділянці оперативної роботи, отримував завдання проникнути всередину націоналістичних формувань для розкладання їх зсередини [20, 351-352]. 3 них особливо цінним був агент-внутрішник - таємний співробітник органів МВС-МДБ, завербований із числа учасників формування супротивника чи введений у формування з метою його розробки [4].

Працездатна і цінна агентура здобувалася шляхом таємного захоплення оунівців під час операцій і вербування на місці. Крім цього, вербувалася агентура з числа розконспірованих розвідників і зв'язкових ОУН, які легально проживали, працювали на підприємствах та в інших господарських організаціях. Наприклад, боєць Кутського винищувального батальйону був розвідником боївки СБ, яку очолював Петро Кузьменюк-«Кордуб». Як було пізніше встановлено, в липні 1945 р. «Кордуб» запропонував йому взяти з собою п’ять учасників ВБ при повному озброєнні і влитися до складу боївки. Встановивши цю обставину, після попередньої оперативної розробки агент СБ був перевербований під псевдом «Луч» і у вказаний день явки за завданням органів МДБ пішов до «Кордуба». Перебуваючи у боївці «Кордуба», агент «Луч» тричі підставляв їі під оперативний удар. Крім того, попередив низку акцій, які готували підпільники $[16,307]$.

Для маскування агентурної сітки створювали легенди про: а) спосіб звільнення 3-під варти; б) зізнання на допитах НКДБ-МДБ, НКВС-МВС; в) способи контакту з ними; г) автобіографічні дані тощо [20, 357]. У боротьбі з оунівським підпіллям вважалося доцільними на кожну групу понад 10 осіб заводити агентурну справу з повною її характеристикою та обов'язковою наявністю агентури, яка їі розробляла. Цінну агентуру в області чи районі на особистий зв'язок брали начальники ВББ, 2-Н чи МВ і РВ НКВС-НКДБ, здійснювали контроль за оперативним складом 3 прийому агентури, проводили міжрайонні операції, заводили міжрайонні агентурні справи на 
діючі відділи, керівництво розробкою яких мали здійснювати відділи ББ, 2-Н [32, 299]. Одночасно для роботи з агентурою і забезпечення зв'язку з нею підготували документ про способи зв'язку з тими, хто вів «розробку» підпілля та його озброєних груп. У ньому рекомендувалися найбільш дієві методи зв'язку: агенти-зв'язники, тайники, конспіративні і явочні квартири, резиденти, домовлені місця зустрічей, знаки і сигнали, прийом агентури в інших районах, тайнопис, двосторонній радіозв'язок з агентурою, сигналізаційний радіопристрій «Метео» [55, 130-131]. Робота органів державної безпеки зі створення агентурного апарату до початку 1946 р. велася у трьох напрямах: вербування агентів-внутрішників, створення інформативної сітки й агентурно-бойових груп у всіх селах, підпілля $[49,107]$. Основний акцент в агентурній роботі МДБ було зроблено на: а) вербування і введення до оунівського підпілля агентури, здатної розробляти і підводити під оперативний удар його учасників; б) виявлення і перехоплення ліній організаційного зв'язку між керівними звенами підпілля ОУН з метою введення у них агентури для захоплення чи ліквідації їхніх керівників; в) перехоплення каналів зв'язку Проводу ОУН у західних областях iз закордонними частинами та введення туди агентури МДБ, захоплення кур'єрів і виходу через них на місця переховування оунівських керівників; г) створення легендованих проводів із кваліфікованої агентури зі завданням підпорядкувати собі нижчестоящі проводи, озброєні групи і їх націоналістичні організації для розкладення зсередини; д) викриття і ліквідація оунівських груп i організацій, учасники яких проживали легально [45, 13-14].

Агентурна робота здійснювалася через відповідно реальні форми справ у апаратах НКДБ: 1) агентурна справа заводилася на групу осіб щодо їхніх зв'язків між собою, спільністю дій, єдиною програмою і метою. Найчастіше за такими справами звинувачувалася і розроблялася група людей, які належали до певної підпільної групи, антирадянської підпільної організації; 2) справа-формуляр заводилася на одну особу; 3) обліково-наглядова справа заводилася на осіб, які хоча і не здійснювали антирадянської діяльності, але за своїм минулим вимагали постійного агентурного нагляду з боку спецслужб; 4) розшукові справи; 5) літерні справи [20, 348]. В обліково-наглядові справи переводилися справи-формуляри, об'єкти розробки яких впродовж тривалого часу не проводили антирадянської діяльності. Включення осіб, які проходили за агентурними справами, справами-формулярами і обліково-наглядовими справами, затверджувалися у 2-у відділі УНКдБ. Справи-формуляри заводилися тільки при наявності первинних агентурних та інших матеріалів. Заведення всіх справ чи їхній перехід з однієї форми в іншу оформлявся постановою, яка реєструвалася у відділі А НКДБ.

Процес вербування був досить тривалим і складався з кількох етапів. Перший - підготовка до вербування агентури, що охоплювала п’ять фаз: а) підбір кандидатури, поверхове ознайомлення з об'єктом. Тут бралися до уваги анкетні дані (вік, національність, освіта, місце проживання, соціальне походження, політичні переконання і притаманні особливості, схильності, пристрасті); б) мета вербування - чітко визначена ділянка роботи агента, його завдання і обов'язки; в) всебічне вивчення кандидатури; г) збір компрометуючих матеріалів; д) особисте знайомство - остання фаза підготовки до вербування агента. Оперативник у розмові перевіряв і уточнював дані про кандидата, отримані агентурним шляхом, і визначав додаткові риси характеру об’єкта.

Другий етап - безпосереднє вербування агентури. Умовою до вербування кожного агента для залучення його до співробітництва на основі компрометуючих матеріалів були особисті зізнання. Для затвердження агентури до обласного УНКДБ відправлялися такі документи: а) протокол допиту об'єкта; б) власноручно написана автобіографія; в) заява про співробітництво; г) спеціальний рапорт начальника РВ НКДБ на затвердження агентури [20, 349-350]. До речі, у підпіллі дуже добре орієнтувалися у роботі спецслужб, знали категорії і будову агентурних сіток [48, 423-443]. Агентурні справи заводилися тоді, коли з'являлася інформація про певний структурний, адміністративний підрозділ $[36,103]$. Для ілюстрації масштабності діяльності наведемо наступні дані. Загалом станом на 1 січня 1945 р. по ВББ і периферійних органах УНКВС Дрогобицької області розроблялося: 55 агентурних справ, 70 справ-формулярів, 88 облікових справ; 3 них по ВББ: п’ять агентурних справ, 13 справ-формулярів, дві облікові справи; по РВ НКВС: 50 агентурних справи, 57 справ-формулярів, 86 облікових справ. Із загального числа реалізовано: 13 агентурних справ, 25 справ-формулярів, вісім облікових справ $[15,5]$. 
Чисельність агентури радянських спецслужб була значною. Станом на 1 липня 1945 р. на обліку НКВС у західних областях України перебували 11214 працівників агентурної сітки (175 резидентів, 1196 агентів, 9843 інформаторів) [68, 21]. За даними сучасних дослідників Д. Вєдєнєєва і Г. Биструхіна, на 1 листопада 1946 р. агентурний апарат МДБ у західному регіоні нараховував 644 резиденти, 2249 агентів та 18165 інформаторів [5, 101]. У Закарпатській області (на 1 вересня 1945 р.) було чотири агентурні розробки, три справи-формуляри, 17 облікових справ, 1030 осіб [10,91]. Станом на 1 липня 1946 р. на обліку в обласних Управліннях МДБ УРСР було 2910 агентурних справ, по них розроблялися 16730 осіб, 31245 справ-формулярів, 6144 обліково-наглядових справ, 8246 справ агентурної розробки, 18797 попередніх агентурних розробок (у Дрогобицькій - 285 агентурних справ, по них розроблялися 1858 осіб, 1409 справ-формулярів, 79 обліково-наглядових справ, 136 справ агентурної розробки, 303 попередніх агентурних розробок; відповідно у Закарпатській - 38/208, 724, 139, 9, 626; Станіславській - 204/1566, 1228, 51, 316, 1106; Чернівецький - 77/482, 647, 294, 71, 324) [56, 58]. На 20 лютого 1947 р. у Дрогобицькій області в УМВС розроблялося шість агентурних справ на 54 особи, вісім справ-формулярів, 21 облікова справа; у міськрайвідділах УМВС - 74 агентурні справи на 756 осіб, 168 справ-формулярів, 872 облікові справи, 13 розшукових справ. Загалом по області опрацьовувалося 80 агентурних справ на 810 осіб, 176 справ-формулярів, 893 облікові справи, 13 розшукових справ [34, 43в.]. Дещо менше розроблялося справ у Чернівецькій області (1 березня 1947 р.): 26 агентурних справ; 86 справ-формулярів, 329 облікових справ, 17 літерних справ, 26 попередніх агентурних справ, 45 розшукових справ [35, 5-6]. У провадженні відділу 2-Н і РВ МДБ Чернівецької області станом на 1 червня 1950 р. числилося у розробці: 39 агентурних справ на 249 осіб, 458 справ-формулярів, 312 обліково-наглядових справ, 7 попередньої агентурної розробки. В тому числі у відділі 2-Н: сім агентурних справ на 28 осіб, 64 справи-формуляри, 40 обліково-наглядових справ, сім попередньої агентурної розробки [28, 48].

На всі проводи ОУН (кущові, районні, надрайонні, окружні, крайові) та відділи УПА заводили агентурні справи, при цьому їх після ліквідації осіб, які за ними проходили, закривали, а при виявленні і відновленні проводів заводили нові (переважно з новими назвами) [23, 3; 34, 5; 52, 163-167], наприклад, № 27 на членів Дрогобицького окружного проводу «Омут» [49, 101; 53, 131; 62, 293]. На 1 січня 1948 р. заведено агентурні справи «Легенда», пізніше «Карпати» на Дрогобицький надрайонний, «Окружні», «Кубло» - Самбірський надрайонний, «Вороги», «Тризуб»- Стрийський надрайонний, «Скитальці» - на учасників друкарні Дрогобицького окружного проводу ОУН (заведена 13 березня 1950 р.). Відтак у Станіславській області заведено агентурні справи «Верховинці» (заведена 14 грудня 1945 р., закрита 27 листопада 1954 р.) на Карпатський крайовий провід ОУН; «Відторгненні» - Станиславівський обласний, «Провокатори» (заведена 5.06.1945р.) - Косівський надрайонний, «Приречені» - Коломийський надрайонний, «Мрійники» - по Закарпатті, «Зав’язка» (заведена 07.1945) на ОУН Закарпатської області, «Гості» - Закарпатті, «Сіроманці» - Калуський окружний (08.1945), «Райх» - Станиславівський окружний, «Підпільники» - Коломийський окружний, «Варвари» - Станиславівський надрайонний (03.1945), «Карпати» - Коломийський окружний, «Вовки» - Коломийський надрайонний, «Ядро» - Косівський надрайонний, «Центр» - Городенківський надрайонний, «Трійка» - Надвірнянський надрайонний, «Керівники» - Тлумацький надрайонний, «Чумаки» - Калуський надрайонний, «Замок» - Долинський надрайонний, «Переправа» - Станиславівський окружний (заведена у лютому 1951 р.), «Перехоплення» - Коломийський окружний (заведена 6 вересня 1951 р.) $[17,1 ; 20,259,262,265,268,272,274,277,279,282,284 ; 21,154 ; 23,3 ; 24,340-341 ; 25,14-15$; 27, 206-207; 34, 5; 41, 68; 39; 40; 8, 296; 9, 380; 10; 11; 50, 249; 51, 185; 52, 163-167; 53, 192, 371].

Паралельно заводилися агентурні справи по ВББ МВС, що свідчить про масштабність роботи спецслужб і намагання якнайшвидше ліквідувати український визвольний рух, здійснюючи паралельну розробку МДБ і МВС: «Петлюрівці» - Карпатський крайовий, «Лісоруби» - Станиславівський окружний (заведена 13.06.1945), «Гірні» - Коломийський окружний (заведена 04.07.1945), «Провідники» - Калуський окружний (заведена 02.03.1945), «Націоналісти» - Долинський надрайонний (заведена 01.03.1945), «Підпільники» - Калуський надрайонний (заведена 07.06.1945), «Кроти» - Тлумацький надрайонний (заведена 10.07.1945), «Степові» - Городенківський надра- 
йонний (заведена 06.06.1945), «Лісні» - Надвірнянський надрайонний (заведена 10.06.1945), «Фанатики» - Станиславівський надрайонний (заведена 02.03.1945), «Жуліки» - Коломийський надрайонний (заведена 03.1945). Водночас по відділу ББ УМВС Чернівецької області (1 березня 1947 р.) «Вурдалаки» - Буковинський окружний, «Кочівники» - Вижницький надрайонний, «Ланка» - Чернівецький надрайонний, «Болото» - Заставнянський надрайонний провід [36, 40, $45,57,61,70,81,87,91,95,98 ; 35,5 ; 34,4$ зв.].

Попри наявність величезної кількості агентів і їхні успіхи у роботі, у 1946 р. чекісти відзначали серйозні недоопрацювання, які суттєво сповільнювали цілковиту ліквідацію підпілля на всій території західних областей України [29, 25]. Однією з таких причин було те, що відправлені працівники відверто не хотіли вести боротьбу із підпіллям. Так, у рапорті заступникові міністра держбезпеки УРСР М. Ступницькому помічник уповноваженого Болехівського райвідділу МДБ Станіславської області Олександр Шамонін 20 вересня 1948 р. повідомляв про небажання вести агентурну роботу проти українського націоналістичного підпілля та просив звільнення. Прохання обгрунтовував тим, що попри власне небажання доля його пов'язала із МДБ, і він потрапив у західні області України (грудень 1945 р., оперуповноваженим Болехівського РВ МДБ). Дізнавшись про принципи оперативної роботи, одразу ж почав відчувати складність роботи 3 агентурою, до якої мав відразу. У процесі трирічної роботи це відчуття не тільки не минуло, навпаки стало ще сильнішим [76, 640-641].

Водночас при роботі з агентурою траплялися й інші недоліки, зокрема у цей період спостерігалися часті порушення правил конспірації. Деякі секретарі РК КП(б)У навіть обговорювали агентурно-інформативну роботу РВ МДБ-МВС на відкритих бюро РК КП(б)У і районних партійних зборах, що призводило до розконспірації методів роботи. При зустрічах з агентурою окремі працівники не дотримувалися правил конспірації [38, 103; 42, 163]. Лише у 1948 р. через недотримання правил конспірації загинули чотири агенти у Хирівському РВ МДБ Дрогобицької області $[61,303]$. Служба безпеки ОУН вдало використовувала численні факти порушення конспірації в агентурній роботі правоохоронних органів. Оргбюро ЦК КП(б)У 9 серпня 1946 р. змушене було ухвалити спеціальну постанову, у якій визнавало: недотримання правил конспірації спричиняло розкриття методів агентурно-оперативної роботи органів МДБ та заходів боротьби 3 повстанцями, націоналістами, а відтак призводило до провалу операцій, марної загибелі працівників і ускладнювало проведення подальших заходів боротьби з підпіллям.

Серед недоліків агентурно-оперативної роботи у звіті від 25 березня 1949 р. самі чекісти називали також небажання окремих керівників, які уникали складних і глибоко продуманих агентурних заходів, ішли шляхом найменшого опору, широко застосовуючи, де потрібно і непотрібно, допити під виглядом СБ, чим розшифровували цей метод роботи. До АБГ часто включали осіб без достатньої перевірки. Так, в Обертинському районі агенти-бойовики Михайло Феній-«Полтавець», «Гонта» і «Гамалія» при виконанні завдання вбили оперативного працівника і старшого АБГ, а потім перейшли в підпілля [54, 269].

Попри значні успіхи в роботі з агентурою, керівництво спецслужб констатувало окремі недоліки, що призводило до перенесення окремими керівниками усієї важкості боротьби з ліквідації підпілля на війська МВС, ВБ. Воно постійно вимагало додаткової кількості військ, скаржилося на слабку ефективність військових операцій, але нічого не робило для того, щоб забезпечити агентурну підготовку кожної операції. Через це ефективність чекістсько-військових операцій залишалася низькою. Так, із 59317 операцій і засідок, проведених на території західних областей України ( 1 квітня до 1 грудня 1946 р.), результати мали тільки 10224 (17\%), в тому числі: у Дрогобицькій проведено операцій і засідок 7789, з них вдалих 2169 (28\%), Станіславській 11 234/2825 (25\%), Чернівецькій 670/81 (12\%) [29, 26]. Попри те, на окремих територіях, незважаючи на колосальні зусилля, масштабні операції були безрезультатними [13, 32-33]. Так, у Чернівецькій області (березень 1947 р.) у ході 866 операцій вбили лише одного повстанця, а 13 втекли [69, 334].

Ще одним недоопрацюванням на думку вищого керівництва МДБ УРСР було те, що частина осіб, залучених до агентурної мережі влаштовувалися до різних закладів, установ, організацій займалися дезінформування, оперативно довідувалися про плановані заходи органів радянської 
влади, отримувати різні документи, кореспонденцію та продовжували вести активну співпрацю із українським визвольним рухом $[64,68]$.

Після постанови ЦК КП(б)У від 10 січня 1945 р. поширення агентурної мережі стало пріоритетним завданням. М. Хрущов запропонував такі методи організації і залучення агентури: викликати з сіл великі групи населення (50-100 осіб) і під час допитів вербувати агентів та інформаторів або зустрічатися зі завербованими $[78,470]$. Відповідно до цих рекомендацій, почали використовувати масові виклики населення для роботи з агентурою та вербування нової. Так, у Дрогобицькій області з 26 січня до 5 лютого 1946 р. із 777 населених пунктів викликали на допити 17872 особи. У результаті цього вдалося завербувати 637 осіб, заарештували 43 пособники, з'явилися з повинною п'ять осіб [73, 430; 74, 430; 71, 604]. У січні 1946 р. масовими викликами у Чернівецькій області охопили 459 населених пунктів (11 364 особи), у результаті яких виявлено 306 осіб, запідозрених у зв'язках із націоналістами - 49 оунівців, 89 пособників, 76 різного антирадянського елементу $[69,68]$. Тільки за 6 лютого 1946 р. Кіцманським і Глибоцьким РВ НКВС проводилися масові виклики населення, якими охопили 12 населених пунктів (283 особи викликали, з них завербували шість таємних інформаторів, взяли на облік за підозрою у зв'язку із підпільниками сім осіб, виявили двох зрадників) $[33,14]$. За добу (6 лютого 1946 р.) у Чернівецькій області масовими викликами населення (924 особи) охопили 49 населених пунктів. Під час цієї акції 10 осіб завербували, 76 дали підписки, шість взяли на облік [33, 38]. У першій половині 1946 р. тривали виклики населення до райвідділів НКВС і НКДБ; із 6 до 15 лютого у Дрогобицькій області було викликано 15608 осіб, з них завербовано 378. 326 лютого до 5 березня того ж року завербовано 106 осіб [72, 308].

Масові виклики практикувалися і в наступні роки. Так, у Дрогобицькій області у січні 1947 p. викликали населення для бесід по лінії РВ МВС - 12/182, по лінії РВ МДБ - 4/90 [63, 56]. Такі дії здійснювалися інколи навіть для зустрічі з особливо важливою агентурою. Так, 8-10 квітня 1947 р. у смт Космач Яблунівського р-ну Станіславської обл. організували масовий виклик населення з метою: а) організації зустрічі з агентом УМДБ «Оксаною»; б) встановлення ймовірних місць переховування підпільників [37, 239]. Водночас відзначимо, що СБ ОУН розробила методи поведінки при проведенні масових викликів: якщо на початковому етапі намагалася перевірити усіх, хто побував на допитах, то пізніше використовувала тактику очікування, спостереження, що довело ефективність, позаяк це притуплювало увагу агентури і можна було ії̈ виявити. СБ також 3 роками перестала одразу ліквідовувати агентуру, натомість намагалися виявити цілий ланцюжок та ліквідувати найбільш активних і небезпечних для націоналістичного руху [70, 6].

Основний акцент робився на використанні агентури, яка мала стати основною зброєю у руках чекіста $[13,40]$. Дослідниця історії національно-визвольного руху Галина Стародубець доходить висновку, що «сексотництво» стало одним із видів колаборації населення повстанського запілля з радянською владою» і завдяки цілеспрямованій політиці з другим приходом органів радянської влади набуло масового характеру $[77,22]$. На підтвердження цього наводимо цифри по областях України, які входили до Карпатського краю. Так, у Дрогобицькій області станом на 1 січня 1945 р. на обліку перебували три резиденти, 25 агентів, 724 інформатори (з них по ВББ: один резидент, 10 агентів, 70 інформаторів; по РВ НКВС: два резиденти, 15 агентів, 654 інформаторів). На 1 квітня 1945 в УНКДБ Дрогобицької області на обліку перебували 13 резидентів, 45 агентів, 1069 інформаторів (всього 1127) [60, 156]. На 1 січня 1945 р. у Станіславській області перебували два резиденти, 120 агентів, 620 інформаторів, всього - 742. На 25 лютого 1945 р. в УНКДБ Станіславської області у складі агентурно-інформативного апарату перебували 65 резидентів, 373 агенти і 2429 інформаторів [6, 56-57]. Натомість у Чернівецькій області (на 1 січня 1945 р.) було сім резидентів, 88 агентів, 351 інформатор (разом 446) [30, 41; 31, 20; 32, 81]. Загальний підсумок залучення до агентурно-інформаційної сітки по всіх західних областях України (на 1 січня 1945 р.) становив: 45 резидентів, 725 агентів, 5628 інформаторів [32, 82]. Агентура радянських спецслужб була значною, на 1 липня 1945 р. в агентурній сітці по західних областях України перебували: 175 резидентів, 1196 агентів, 9843 інформаторів [32, 83]. Агентурно-інформативна сітка була достатньо динамічною, їі чисельність поступово змінювалася за рахунок включення нових 
агентів, вибуття (в ЧА-РА, ФЗН, виключення через розконспірацію, загибель, зникнення безвісти, переведення в інші органи) [59, 1-2; 18, 286; 12, 37; 62, 294; 68, 21].

Стан агентурно-інформаційної сітки допомагає простежити узагальнена довідка по УНКВС західних областей України. Зокрема, у Дрогобицькій області: на 1 жовтня 1945 р. - 87 резидентів, 138 агентів, 1755 інформаторів (разом 1980); на 1 січня 1946 р. - 92 резиденти, 176 агентів, 1821 інформатор (разом 2089); у Станіславській області: на 1 жовтня 1945 р. - 11 резидентів, 190 агентів, 1504 інформаторів (разом 1 705); на 1 січня 1946 р. - 13 резидентів, 271 агентів, 1739 інформаторів (разом 2023); у Чернівецькій області: на 1 жовтня 1945 р. - 38 резидентів, 136 агентів, 829 інформаторів (разом 1 003); на 1 січня 1946 р. - 38 резидентів, 128 агентів, 877 інформаторів (разом 1043) [30, 41]. Не слід забувати і про те, що у цей час паралельно діяла агентурна мережа інших органів.

Натомість інші документи подають дещо вищі цифри по усіх областях агентурно-інформативного апарату. Агентурно-інформативна сітка НКВС Станіславської області: на 1 жовтня 1945 р. - 18 резидентів, 207 агентів, 1684 інформатори [12, 55]; агентурно-інформативна сітка НКВС Чернівецької області: 52 резиденти, 134 агенти, 1039 інформаторів [12, 67]. У відділі ББ НКВС Закарпатської області на 1 вересня 1945 р. перебувало 12 агентів та 169 інформаторів [10, 91]. УНКВС Дрогобицької області на 1 березня 1946 р. на обліку мала: 91 резидента, 174 агенти, 104 агенти-внутрішники, 70 маршрутників, 1843 таємних інформатори [18, 6, 67]; вже на 1 листопада 1946 р. перебували 276 агентів, 145 резидентів, 2330 інформаторів [19, 134].

Агентурна мережа НКДБ у Станіславській області станом на 25 липня 1946 р. складала 6405 осіб: 641 агент, 142 резиденти, 5572 інформатори, 41 утримувач явочних і конспіративних квартир [2, 134; 3, 651-653].

Щодо наявності агентів існують досить суперечливі дані, які часто змінювалися, як і більшість звітних документів [3, 651-653]. Порівнюючи роботу (липень-серпень 1946 р.) з агентурою Дрогобицької і Станіславської областей, які відзначалися найбільшою концентрацією націоналістів, зауважимо: чекісти Дрогобицької працювали більш інтенсивно, оскільки там передбачалося завербувати 156 резидентів (53 фактично завербовано, 103 недовербовано), 484 агенти (77/307), 1435 інформаторів (366 фактично завербовано, 1069 недовербовано), конспіративних і явочних квартир не було (0/0). У Станіславській області передбачалося завербувати 120 резидентів (67 фактично завербовано, 53 недовербовано), 319 агентів (232 фактично завербовано, 87 недовербовано), інформаторів не було (0/0), 101 конспіративну і явочну квартиру (34 фактично завербовано, 67 недовербовано) [13, 38; 29, 36].

У 1946 р. завербовано по західних областях України 479 резидентів, 1536 агентів, 10411 інформаторів (всього 12 426). Упродовж цього часу виключено: 102 резиденти, 1026 агентів, 5051 інформатора (всього 6179). На 1 листопада 1946 р. перебувало: 644 резиденти, 2249 агентів, 18165 інформаторів (всього 21 058) [13, 29; 29, 28].

Серед наявних 2249 агентів було 1275 агентів-маршрутників. До цієї категорії, як правило, УМВC і РВ МВС відносили всіх агентів, які не працювали по конкретних справах, чи були завербовані без урахування необхідності в маршрутній агентурі. Ці маршрутники здебільшого були рядовими інформаторами. Натомість агентів-внутрішників було лише 974. Але ця цифра не відповідала дійсності, оскільки більшість із них не мала доступу до оунівського підпілля і, по суті, не були внутрішниками. Наявні 974 агенти-внутрішники у середньому розподілялися по 140 на область $[13,30 ; 29,29]$. Відзначалося істотне збільшення резидентів. Якщо на 1 січня 1946 р. у західних областях України нараховувалося 277 резидентур, то на 1 листопада 1946 р. їх було 644, на зв'язку у резидентів перебували 3183 інформатори [29, 27].

В УМВС Дрогобицької області на 1 січня 1947 р. перебували 143 резиденти, 278 агентів (серед них 118 агентів-внутрішники, 124 агенти-маршрутники, два агенти-вербувальники, п’ять агентів-зв'язників, 29 агентів-бойовиків) та 2334 інформатори $[18,286] .20$ лютого 1947 р. 3 УМВС в УМДБ передали 2088 агентів: у ВББ УМВС: чотири агенти, 16 агентів-бойовиків, чотири резиденти, один утримувач явочних квартир, 46 інформаторів; у міськрайвідділах: 115 агентів, 17 агентів-бойовиків, 90 резидентів, двоє утримувачів явочних квартир, 1793 інформаторів [34, 4]. На 14 лютого 1947 р. в УМВС Станіславської області перебувало 3677 особових справ на 
агентурно-інформативну сітку (89 резидентів, 557 агентів, 12 утримувачів конспіративних квартир, 3002 інформатори) [36, 3]. Загалом по УМДБ Станіславської області (на 25 березня 1947 р.) перебувало агентури по лінії ОУН: 141 резидент, 495 агентів, 4112 інформаторів, 35 утримувачів конспіративних квартир [21, 106]. На 1 травня 1947 р. агентурно-інформаційна сітка по лінії відділу 2-Н складала 5119 осіб, з них: 512 агентів, 4427 інформаторів, 144 резиденти, 36 утримувачів конспіративних квартир [22, 157].

1 лютого 1948 р. у Дрогобицькій області обліковувалося: 145 резидентів, 426 агентів, 4092 інформатори [57, 27, 38-38зв.]. Головним інструментом органів держбезпеки у боротьбі проти визвольного руху все-таки був агентурний апарат. Так, за січень 1949 р. у Дрогобицькій області з 59 успішних оперативно-військових заходів 40 здійснено за агентурними даними [5, 275]. На 1 червня 1949 р. агентурний апарат складався з 5046 осіб, в тому числі: 618 агентів, 138 резидентів, 4263 інформатори, 28 утримувачів конспіративних квартир [24, 248].

Агентурно-інформативний апарат Управління і міськрайвідділів МДБ Станіславської області по лінії відділу 2-Н на 23 серпня 1949 р. складався з 5003 осіб (604 агенти, 4231 інформатор, 139 резидентів, 29 утримувачів конспіративних квартир) [25, 69]. Агентурно-інформативний апарат Управління і міськрайвідділів МДБ Станіславської області по лінії відділу 2-Н на 25 жовтня 1949 р. мав 4985 осіб, у тому числі: 593 агенти, 4230 інформаторів, 135 резидентів, 27 утримувачів конспіративних квартир [25, 130-131].

Агентурно-інформативний апарат Управління і міськрайвідділів МДБ Станіславської області по лінії відділу 2-Н на 1 січня 1950 р. дещо зменшився і складався з 4970 осіб (600 агентів, 4211 інформаторів, 132 резидентів, 27 утримувачів конспіративних квартир). Вербування продовжувалося і на завершальному етапі боротьби. Так, у січні 1950 р. Управління і міськрайвідділи МДБ завербували 168 осіб (17 агентів, одного резидента, 139 інформаторів, одного утримувача конспіративних квартир) $[25,197]$. Натомість значно меншими масштабами роботи відзначалося УМДБ Чернівецької області, яке впродовж жовтня 1949 р. - 1 червня 1950 р. завербувало: одного резидента, 10 агентів, 47 інформаторів. За цей період виключено і передано в інші органи: одного резидента, 20 агентів, 64 інформатори [28, 49]. Станом на 1 червня 1950 р. в УМДБ Чернівецької області агентурно-інформативний апарат по лінії 2-Н складався 3: 34 резидентів, 297 агентів, 1023 інформаторів, 11 конспіративних квартир [28, 49]. УМДБ Чернівецької області на 1 липня 1951 р. облікував наявних: 33 резидентів, 299 агентів, 996 інформаторів, 11 конспіративних квартир [7, 64]. На 25 серпня 1951 р. в УМДБ Дрогобицької області перебували: 51 агент, 29 резидентів, 384 інформатори, 25 утримувачів явочних квартир [46, 175]. Відтак на 25 грудня 1951 р. стало: 52 агенти, 30 резидентів, 368 інформаторів, 24 утримувачі явочних квартир [46, 203].

Водночас самі чекісти відзначали суттєві недоліки у використанні агентурно-інформативного апарату: внутрішньої агентури, здатної вести глибоку розробку підпілля, було вкрай мало, а над питаннями ії здобуття органи МДБ працювали недостатньо, слабкою була робота зі створення агентурної сітки. Констатувалося: незважаючи на те, що в 1951 р. органами МДБ західних областей України в ході проведення заходів з ліквідації підпілля було негласно виведено з повинною і захоплено 576 підпільників і учасників ОУН, із цієї кількості органами МДБ завербовано тільки 70 агентів, з числа яких 22 агентів-внутрішників залишено на нелегальному становищі і введено до підпілля. У тому числі по областях: Станіславській - 241/37/10; Дрогобицькій - 111/10/2; Тернопільській - 58/7/2; Львівській - 76/3/1; Волинській - 40/4/2; Рівненській - 36/7/3; Закарпатській - 10/2/2; Чернівецькій - 4/0/0 [45, 14-15]. На думку Г. Стародубець, «найвиразнішим показником деформування суспільної моралі повстанського запілля стало масове поширення такого явища, як сексотництво» $[77,19]$.

У ході проведених у 1951 р. оперативних заходів спецслужби захопили 419 підпільників і учасників ОУН, з них: у Станіславській області (1951) - 196 (37 оперативно використовувалися), 1950 р. - 141; Дрогобицькій (1951) - 55 (10), 1950 р. - 133; Закарпатській (1951) - вісім (два), 1950 р. - чотири захоплено; Чернівецькій (1951) - чотири (оперативно не використовувалися), 1950 р. - вісім. Отже, разом в 1951 р. захоплено 419 (70 оперативно використовувалися), 1950 р. $553[14,6]$. У 1952 р. простежується тенденція до скорочення агентурної сітки в обласних УМДБ. Так, якщо 1 січня 1952 р. в агентурній сітці відділу 2-Н УМДБ Дрогобицької області перебували 
307 агентів, то на 1 вересня їх залишилося 158, тобто скорочення склало на 48,5\%. В агентурній сітці міськрайорганів МДБ на 1 січня 1952 р. перебували 8260 агентів, на 1 вересня залишилося 3876 (тобто скоротилася на 53\%). У провадженні відділу 2-Н на 1 січня було 10 агентурних справ i 91 справа-формуляр. У результаті перегляду оперативних обліків для подальшої розробки у відділі 2-Н залишено відповідно дві агентурні справи і 88 справ-формулярів $[58,65]$. У міськрайорганах МДБ на 1 січня у провадженні було 317 агентурних справ і 5106 справ-формулярів (заведених на учасників підпілля і їх пособників), а 1 вересня залишилося 188 (59,3\%) і 2287 (44,8\%) $[43,185 ; 58,66]$.

У січні 1952 р. до розробки структур ОУН, що діяли у Станіславській області, було залучено 749 агентів і 5976 інформаторів [44, 4]. Тоді ж у Чернівецькій області по розробці учасників Буковинського окружного проводу ОУН Ю. Матвіїва-«Недобитого» працювали три агенти і п'ять інформаторів, а також агентурно-бойова група у складі чотирьох агентів-бойовиків [44, 5]. Загалом на 10 січня 1952 р. в УМДБ Дрогобицької області по оунівських проводах працювали 58 агентів, 246 інформаторів, по збройних групах - 17 агентів, 182 інформатори [44, 9]. Таким чином, вищенаведені документи засвідчують величезні масштаби залучення агентури до боротьби з українським визвольним рухом. Щоправда, ії діяльність не завжди була ефективною.

Висновки. Отже, сподівання органів радянської влади на швидку та повну ліквідацію визвольного руху не виправдалися. Тому масового поширення набуло використання агентури у всіх можливих формах. Характерно, що роботі з агентурою у комплексі протинаціоналістичних заходів відводилося центральне місце. Відзначимо, що цей засіб боротьби довів свою чи не найбільшу ефективність. Однак, незважаючи на масовий тиск, використання брутальних методів боротьби репресивно-каральних органів проти українського визвольного руху, підпілля у Карпатському краї ОУН користувалося широкою підтримкою населення, що забезпечувало йому успіх у протистоянні з радянським тоталітаризмом.

\section{СПИСОК ВИКОРИСТАНИХ ДЖЕРЕЛ І ЛІТЕРАТУРИ}

1. Burds J. Agentura: Soviet Informants' Networks and the Ukrainian Rebel Underground in Galicia 1944 - 1948 / Jeffrey Burds // Eastern European Policy and Society (EEPS). - Vol. 1. - Number 1 (winter 1997). P. $119-120$.

2. Білас I. Репресивно-каральна система в Україні 1917 - 1953. Суспільно-політичний та історико-правовий аналіз. У двох книгах / І. Білас. - К.: Либідь - Військо України, 1994. - Кн. 1. - 432 с.

3. Білас I. Репресивно-каральна система в Україні 1917 - 1953: суспільно-політичний та історичний аналіз. У двох книгах / Іван Білас. - К.: Либідь; Військо України, 1994. - Кн. 2: Документи та матеріали. $688 \mathrm{c}$.

4. Бурдс Д. «Москальки»: женщины-агенты и националистическое подполье на Западной Украине, 1944 - 1948 / Д. Бурдс. [Електронний ресурс]. - Режим доступу: URL: http://www.history.neu.edu/fac/burds/ Burds-Moskalki.pdf (15.11.2004). - Назва екрану.

5. Вєдєнєєв Д. Двобій без компромісів. Протиборство спецпідрозділів ОУН та радянських сил спецоперацій. 1945 - 1980-ті роки: Монографія / Дмитро Вєдєнєєв, Геннадій Биструхін. - К.: К.І.С., 2007. - 568 с.

6. ГДА СБУ. - Ф. 2-Н. - Оп. 106 (1954). - Спр. 1.

7. ГДА СБУ. - Ф. 2-Н. - Оп. 106 (1954). - Спр. 2.

8. ГДА СБУ. - Ф. 2-Н. - Оп. 110 (1954). - Спр. 2. - Т. 5.

9. ГДА СБУ. - Ф. 2-Н. - Оп. 110 (1954). - Спр. 2. - Т. 8.

10. ГДА СБУ. - Ф. 2-Н. - Оп. 35 (1960). - Спр. 1.

11. ГДА СБУ. - Ф. 2-Н. - Оп. 35 (1960). - Спр. 2.

12. ГДА СБУ. - Ф. 2-Н. - Оп. 36 (1960). - Спр. 1.

13. ГДА СБУ. - Ф. 2-Н. - Оп. 36 (1960). - Спр. 3.

14. ГДА СБУ. - Ф. 2-Н. - Оп. 39 (1960). - Спр. 9.

15. ГДА СБУ. - Ф. 2-Н. - Оп. 55 (1953). - Спр. 12.

16. ГДА СБУ. - Ф. 2-Н. - Оп. 55 (1953). - Спр. 5. - Т. 1.

17. ГДА СБУ. - Ф. 2-Н. - Оп. 55 (1953). - Спр. 6. - Т. 1.

18. ГДА СБУ. - Ф. 2-Н. - Оп. 56 (1953). - Спр. 4. - Т. 3.

19. ГДА СБУ. - Ф. 2-Н. - Оп. 56 (1953). - Спр. 6. - Т. 4.

20. ГДА СБУ. - Ф. 2-Н. - Оп. 56 (1953). - Спр. 6. - Т. 5.

21. ГДА СБУ. - Ф. 2-Н. - Оп. 57 (1953). - Спр. 1. - Т. 1. 
22. ГДА СБУ. - Ф. 2-Н. - Оп. 57 (1953). - Спр. 1. - Т. 2.

23. ГДА СБУ. - Ф. 2-Н. - Оп. 58 (1953). - Спр. 2. - Т. 1.

24. ГДА СБУ. - Ф. 2-Н. - Оп. 59 (1953). - Спр. 6. - Т. 1.

25. ГДА СБУ. - Ф. 2-Н. - Оп. 59 (1953). - Спр. 7. - Т. 2.

26. ГДА СБУ. - Ф. 2-Н. - Оп. 60 (1953). - Спр. 16.

27. ГДА СБУ. - Ф. 2-Н. - Оп. 60 (1953). - Спр. 3. - Т. 6.

28. ГДА СБУ. - Ф. 2-Н. - Оп. 60 (1953). - Спр. 4. - Т. 2.

29. ГДА СБУ. - Ф. 2-Н. - Оп. 70 (1953). - Спр. 6. - Т. 2.

30. ГДА СБУ. - Ф. 2-Н. - Оп. 75 (1953). - Спр. 3.

31. ГДА СБУ. - Ф. 2-Н. - Оп. 75 (1953). - Спр. 4.

32. ГДА СБУ. - Ф. 2-Н. - Оп. 75 (1953). - Спр. 5.

33. ГДА СБУ. - Ф. 2-Н. - Оп. 89 (1951). - Спр. 47.

34. ГДА СБУ. - Ф. 2-Н. - Оп. 90 (1951). - Спр. 62.

35. ГДА СБУ. - Ф. 2-Н. - Оп. 90 (1951). - Спр. 64.

36. ГДА СБУ. - Ф. 2-Н. - Оп. 90 (1951). - Спр. 66.

37. ГДА СБУ. - Ф. 2-Н. - Оп. 93 (1954). - Спр. 2.

38. ГДА СБУ. - Ф. 2-Н. - Оп. 98 (1954). - Спр. 1. - Т. 2.

39. ГДА СБУ. - Ф. 2-Н. - Оп. 98 (1954). - Спр. 14.

40. ГДА СБУ. - Ф. 2-Н. - Оп. 98 (1954). - Спр. 18. - Т. 1.

41. ГДА СБУ. - Ф. 2-Н. - Оп. 98 (1954). - Спр. 7.

42. ГДА СБУ. - Ф. 2-Н. - Оп. 99 (1954). - Спр. 2. - Т. 1.

43. ГДА СБУ. - Ф. 2-Н. - Оп. 99 (1954). - Спр. 2. - Т. 6.

44. ГДА СБУ. - Ф. 2-Н. - Оп. 99 (1954). - Спр. 8. - Т. 2.

45. ГДА СБУ. - Ф. 2-Н. - Оп. 99 (1954). - Спр. 8. - Т. 3.

46. ГДА СБУ. - Ф. 3. - Оп. 246 (1953). - Спр. 4.

47. ГДА СБУ. - Ф. 13. - Спр. 372. - Т. 22.

48. ГДА СБУ. - Ф. 13. - Спр. 372. - Т. 23.

49. ГДА СБУ. - Ф. 13. - Спр. 372. - Т. 55.

50. ГДА СБУ. - Ф. 13. - Спр. 372. - Т. 56.

51. ГДА СБУ. - Ф. 13. - Спр. 372. - Т. 63.

52. ГДА СБУ. - Ф. 13. - Спр. 372. - Т. 72.

53. ГДА СБУ. - Ф. 13. - Спр. 372. - Т. 77.

54. ГДА СБУ. - Ф. 13. - Спр. 372. - Т. 83.

55. ГДА СБУ. - Ф. 13. - Спр. 372. - Т. 90.

56. ГДА СБУ. - Ф. 16. - Оп. 7. - Спр. 4. - Т. 13.

57. ГДА СБУ. - Ф. 71. - Оп. 6. - Спр. 180.

58. ГДА СБУ. - Ф. 71. - Оп. 6. - Спр. 278.

59. ГДА СБУ. - Ф. 71. - Оп. 6. - Спр. 48.

60. ГДА СБУ. - Ф. 71. - Оп. 6. - Спр. 88.

61. ГДА СБУ. - Ф. 71. - Оп. 10. - Спр. 24.

62. ДАЛО. - Ф. П-5001. - Оп. 6. - Спр. 58.

63. ДАЛО. - Ф. П-5001. - Оп. 8. - Спр. 261.

64. Ільницький В. Основні форми співпраці українського визвольного руху з різними соціальними групами населення у Карпатському краї ОУН / В. Ільницький // Східноєвропейський історичний вісник / [головний редактор В. Ільницький]. - Дрогобич: Посвіт, 2017. - Вип. 2. - С. 31-49.

65. Кентій А. В. Українська повстанська армія в 1944 - 1945 pp. / А. В. Кентій. - К.: Інститут історії України НАН України, 1999. - 220 с.

66. Киричук Ю. Нариси з історії українського національно-визвольного руху 40-50-х років XX століття / Ю. Киричук. - Львів: ЛДУ імені Івана Франка, 2000. - 304 с.

67. Киричук Ю. Український національний рух 40-50-х років XX століття: ідеологія та практика / Ю. Киричук. - Львів: Добра справа, 2003. - 464 с.

68. Літопис Української Повстанської Армії. - Т. 43: Боротьба з агентурою: Протоколи допитів Служби безпеки ОУН в Тернопільщині. 1946 - 1948 / [відп. ред. Петро Потічний]. - Торонто; Львів: Літопис УПА, 2006. - Кн. 1. - 1132 c.

69. Літопис Української Повстанської Армії. Нова серія. - Т. 5: Боротьба проти УПА і націоналістичного підпілля: інформаційні документи ЦК КП(б)У, обкомів партії, НКВС-МВС, МДБ-КДБ (1943 - 1959) 
/ [упоряд. Анатолій Кентій, Володимир Лозицький, Ірина Павленко]. - К.; Торонто: Літопис УПА, 2002. Кн. 2: 1946 - 1947. -572 с.

70. Методи боротьби большевиків 3 нами й наша протидія (Санітарна опіка. 1.1.[19]47) // Архів ЦДВР. - Ф. 9. - 7 арк.

71. Науменко К. Карально-репресивна система СРСР як головний інструмент радянізації Львівщини (1944 - 1953) / Кім Науменко // Реабілітовані історією. У двадцяти семи томах. Львівська область. - Львів: Астролябія, 2009. - Кн. 1. - С. 596-609.

72. Русначенко А. М. Народ збурений: Національно-визвольний рух в Україні й національні рухи опору в Білорусії, Литві, Латвії, Естонії у 1940 - 50-х роках / А. М. Русначенко. - К.: Університетське видавництво «Пульсари», 2002. - 519 с.

73. Сергійчук В. Десять буремних літ. Західноукраїнські землі у $1944-1953$ рр. Нові документи і матеріали / Володимир Сергійчук. - К.: Дніпро, 1998. - 944 с.

74. Сергійчук В. ОУН-УПА в роки війни. Нові документи і матеріали / Володимир Сергійчук. - К.: Дніпро, 1996. - 496 с.

75. Сергійчук В. Тавруючи визвольний прапор. Діяльність агентури та спецбоївок НКВС-НКДБ під виглядом ОУН-УПА. Видання друге, доповнене / Володимир Сергійчук. - К.: ПП Сергійчук М.І., 2006. $184 \mathrm{c}$.

76. Сергійчук В. Український здвиг: Прикарпаття. 1939 - 1955 рр. / Володимир Сергійчук. - Київ: Українська Видавнича Спілка, 2005. - 840 с.

77. Стародубець Г. Прояви сексотництва у повстанському запіллі в $1944-1945$ рр. / Г. Стародубець // Мандрівець. - 2006. - Вип. 1(60). - С. 19-22.

78. Український національно-визвольний рух на Прикарпатті в XX столітті. Документи і матеріали / [відп. ред. проф. Микола Кугутяк]. - Т. 2. - Івано-Франківськ: КПФ «ЛІК», 2009. - Кн. 1 : 1939 - 1945. - 600 с.

79. Центральний державний архів вищих органів влади та управління України. - Ф. 3833. - Оп. 1. Спр. 126.

80. Шаповал Ю. Війна після війни / Ю. Шаповал // Літопис УПА. Нова серія. - Т. 3: Боротьба проти УПА і націоналістичного підпілля: директивні документи ЦК Компартії України. 1943 - 1959. - КиївТоронто, 2001. - С. 9-40.

\section{REFERENCES}

1. Burds J. Agentura: Soviet Informants Networks and the Ukrainian Rebel Underground in Galicia 1944 - 1948 / Jeffrey Burds // Eastern European Policy and Society (EEPS). - Vol. 1. - Number 1 (winter 1997). P. $119-120$.

2. Bilas I. Represyvno-karalna systema v Ukraini 1917 - 1953. Suspilno-politychnyi ta istoryko-pravovyi analiz. U dvokh knyhakh / I. Bilas. - K.: Lybid - Viisko Ukrainy, 1994. - Kn. 1. - 432 s.

3. Bilas I. Represyvno-karalna systema v Ukraini 1917 - 1953: suspilno-politychnyi ta istorychnyi analiz. U dvokh knyhakh / Ivan Bilas. - K.: Lybid; Viisko Ukrainy, 1994. - Kn. 2: Dokumenty ta materialy. - 688 s.

4. Burds D. «Moskalky»: zhenshchynы-ahentы y natsyonalystycheskoe podpole na Zapadnoi Ukrayne, 1944 - 1948 / D. Burds. [Elektronnyi resurs]. - Rezhym dostupu: URL: http://www.history.neu.edu/fac/burds/ Burds- Moskalki.pdf (15.11.2004). - Nazva ekranu.

5. Viedienieiev D. Dvobii bez kompromisiv. Protyborstvo spetspidrozdiliv OUN ta radianskykh syl spetsoperatsii. 1945 - 1980-ti roky: Monohrafiia / Dmytro Viedienieiev, Hennadii Bystrukhin. - K.: K.I.S., 2007. $568 \mathrm{~s}$.

6. HDA SBU. - F. 2-N. - Op. 106 (1954). - Spr. 1.

7. HDA SBU. - F. 2-N. - Op. 106 (1954). - Spr. 2.

8. HDA SBU. - F. 2-N. - Op. 110 (1954). - Spr. 2. - T. 5.

9. HDA SBU. - F. 2-N. - Op. 110 (1954). - Spr. 2. - T. 8.

10. HDA SBU. - F. 2-N. - Op. 35 (1960). - Spr. 1.

11. HDA SBU. - F. 2-N. - Op. 35 (1960). - Spr. 2.

12. HDA SBU. - F. 2-N. - Op. 36 (1960). - Spr. 1.

13. HDA SBU. - F. 2-N. - Op. 36 (1960). - Spr. 3.

14. HDA SBU. - F. 2-N. - Op. 39 (1960). - Spr. 9.

15. HDA SBU. - F. 2-N. - Op. 55 (1953). - Spr. 12.

16. HDA SBU. - F. 2-N. - Op. 55 (1953). - Spr. 5. - T. 1.

17. HDA SBU. - F. 2-N. - Op. 55 (1953). - Spr. 6. - T. 1.

18. HDA SBU. - F. 2-N. - Op. 56 (1953). - Spr. 4. - T. 3.

19. HDA SBU. - F. 2-N. - Op. 56 (1953). - Spr. 6. - T. 4. 
20. HDA SBU. - F. 2-N. - Op. 56 (1953). - Spr. 6. - T. 5.

21. HDA SBU. - F. 2-N. - Op. 57 (1953). - Spr. 1. - T. 1.

22. HDA SBU. - F. 2-N. - Op. 57 (1953). - Spr. 1. - T. 2.

23. HDA SBU. - F. 2-N. - Op. 58 (1953). - Spr. 2. - T. 1.

24. HDA SBU. - F. 2-N. - Op. 59 (1953). - Spr. 6. - T. 1.

25. HDA SBU. - F. 2-N. - Op. 59 (1953). - Spr. 7. - T. 2.

26. HDA SBU. - F. 2-N. - Op. 60 (1953). - Spr. 16.

27. HDA SBU. - F. 2-N. - Op. 60 (1953). - Spr. 3. - T. 6.

28. HDA SBU. - F. 2-N. - Op. 60 (1953). - Spr. 4. - T. 2.

29. HDA SBU. - F. 2-N. - Op. 70 (1953). - Spr. 6. - T. 2.

30. HDA SBU. - F. 2-N. - Op. 75 (1953). - Spr. 3.

31. HDA SBU. - F. 2-N. - Op. 75 (1953). - Spr. 4.

32. HDA SBU. - F. 2-N. - Op. 75 (1953). - Spr. 5.

33. HDA SBU. - F. 2-N. - Op. 89 (1951). - Spr. 47.

34. HDA SBU. - F. 2-N. - Op. 90 (1951). - Spr. 62.

35. HDA SBU. - F. 2-N. - Op. 90 (1951). - Spr. 64.

36. HDA SBU. - F. 2-N. - Op. 90 (1951). - Spr. 66.

37. HDA SBU. - F. 2-N. - Op. 93 (1954). - Spr. 2.

38. HDA SBU. - F. 2-N. - Op. 98 (1954). - Spr. 1. - T. 2.

39. HDA SBU. - F. 2-N. - Op. 98 (1954). - Spr. 14.

40. HDA SBU. - F. 2-N. - Op. 98 (1954). - Spr. 18. - T. 1.

41. HDA SBU. - F. 2-N. - Op. 98 (1954). - Spr. 7.

42. HDA SBU. - F. 2-N. - Op. 99 (1954). - Spr. 2. - T. 1.

43. HDA SBU. - F. 2-N. - Op. 99 (1954). - Spr. 2. - T. 6.

44. HDA SBU. - F. 2-N. - Op. 99 (1954). - Spr. 8. - T. 2.

45. HDA SBU. - F. 2-N. - Op. 99 (1954). - Spr. 8. - T. 3.

46. HDA SBU. - F. 3. - Op. 246 (1953). - Spr. 4.

47. HDA SBU. - F. 13. - Spr. 372. - T. 22.

48. HDA SBU. - F. 13. - Spr. 372. - T. 23.

49. HDA SBU. - F. 13. - Spr. 372. - T. 55.

50. HDA SBU. - F. 13. - Spr. 372. - T. 56.

51. HDA SBU. - F. 13. - Spr. 372. - T. 63.

52. HDA SBU. - F. 13. - Spr. 372. - T. 72.

53. HDA SBU. - F. 13. - Spr. 372. - T. 77.

54. HDA SBU. - F. 13. - Spr. 372. - T. 83.

55. HDA SBU. - F. 13. - Spr. 372. - T. 90.

56. HDA SBU. - F. 16. - Op. 7. - Spr. 4. - T. 13.

57. HDA SBU. - F. 71. - Op. 6. - Spr. 180.

58. HDA SBU. - F. 71. - Op. 6. - Spr. 278.

59. HDA SBU. - F. 71. - Op. 6. - Spr. 48.

60. HDA SBU. - F. 71. - Op. 6. - Spr. 88.

61. HDA SBU. - F. 71. - Op. 10. - Spr. 24.

62. DALO. - F. P-5001. - Op. 6. - Spr. 58.

63. DALO. - F. P-5001. - Op. 8. - Spr. 261.

64. Ilnytskyi V. Osnovni formy spivpratsi ukrainskoho vyzvolnoho rukhu z riznymy sotsialnymy hrupamy naselennia u Karpatskomu krai OUN / V. Ilnytskyi // Skhidnoievropeiskyi istorychnyi visnyk / [holovnyi redaktor V. Ilnytskyi]. - Drohobych: Posvit, 2017. - Vyp. 2. - S. 31-49.

65. Kentii A. V. Ukrainska povstanska armiia v 1944 - 1945 rr. / A. V. Kentii. - K.: Instytut istorii Ukrainy NAN Ukrainy, 1999. - $220 \mathrm{~s}$.

66. Kyrychuk Yu. Narysy z istorii ukrainskoho natsionalno-vyzvolnoho rukhu 40-50-kh rokiv XX stolittia / Yu. Kyrychuk. - Lviv: LDU imeni Ivana Franka, 2000. - 304 s.

67. Kyrychuk Yu. Ukrainskyi natsionalnyi rukh 40-50-kh rokiv XX stolittia: ideolohiia ta praktyka / Yu. Kyrychuk. - Lviv: Dobra sprava, 2003. - 464 s.

68. Litopys Ukrainskoi Povstanskoi Armii. - T. 43: Borotba $\mathrm{z}$ ahenturoiu: Protokoly dopytiv Sluzhby bezpeky OUN v Ternopilshchyni. 1946 - 1948 / [vidp. red. Petro Potichnyi]. - Toronto; Lviv: Litopys UPA, 2006. - Kn. 1. $1132 \mathrm{~s}$. 
69. Litopys Ukrainskoi Povstanskoi Armii. Nova seriia. - T. 5: Borotba proty UPA i natsionalistychnoho pidpillia: informatsiini dokumenty TsK KP(b)U, obkomiv partii, NKVS-MVS, MDB-KDB (1943 - 1959) / [uporiad. Anatolii Kentii, Volodymyr Lozytskyi, Iryna Pavlenko]. - K.; Toronto: Litopys UPA, 2002. - Kn. 2: 1946 - 1947. $572 \mathrm{~s}$.

70. Metody borotby bolshevykiv z namy y nasha protydiia (Sanitarna opika. 1.1.[19]47) // Arkhiv TsDVR. F. 9. -7 ark.

71. Naumenko K. Karalno-represyvna systema SRSR yak holovnyi instrument radianizatsii Lvivshchyny (1944 - 1953) / Kim Naumenko // Reabilitovani istoriieiu. U dvadtsiaty semy tomakh. Lvivska oblast. - Lviv: Astroliabiia, 2009. - Kn. 1. - S. 596-609.

72. Rusnachenko A. M. Narod zburenyi: Natsionalno-vyzvolnyi rukh v Ukraini y natsionalni rukhy oporu v Bilorusii, Lytvi, Latvii, Estonii u 1940 - 50-kh rokakh / A. M. Rusnachenko. - K.: Universytetske vydavnytstvo «Pulsary», 2002. - 519 s.

73. Serhiichuk V. Desiat buremnykh lit. Zakhidnoukrainski zemli u $1944-1953$ rr. Novi dokumenty i materialy / Volodymyr Serhiichuk. - K.: Dnipro, 1998. - 944 s.

74. Serhiichuk V. OUN-UPA v roky viiny. Novi dokumenty i materialy / Volodymyr Serhiichuk. - K.: Dnipro, 1996. $-496 \mathrm{~s}$.

75. Serhiichuk V. Tavruiuchy vyzvolnyi prapor. Diialnist ahentury ta spetsboivok NKVS-NKDB pid vyhliadom OUN-UPA. Vydannia druhe, dopovnene / Volodymyr Serhiichuk. - K.: PP Serhiichuk M.I., 2006. $184 \mathrm{~s}$.

76. Serhiichuk V. Ukrainskyi zdvyh: Prykarpattia. 1939 - 1955 rr. / Volodymyr Serhiichuk. - Kyiv: Ukrainska Vydavnycha Spilka, 2005. - $840 \mathrm{~s}$.

77. Starodubets H. Proiavy seksotnytstva u povstanskomu zapilli v $1944-1945$ rr. / H. Starodubets // Mandrivets. - 2006. - Vyp. 1(60). - S. 19-22.

78. Ukrainskyi natsionalno-vyzvolnyi rukh na Prykarpatti v KhKh stolitti. Dokumenty i materialy / [vidp. red. prof. Mykola Kuhutiak]. - T. 2. - Ivano-Frankivsk: KPF «LIK», 2009. - Kn. 1: 1939 - 1945. - 600 s. 126.

79. Tsentralnyi derzhavnyi arkhiv vyshchykh organiv vlady ta upravlinnia Ukrainy. - F. 3833. - Op. 1. - Spr.

80. Shapoval Yu. Viina pislia viiny / Yu. Shapoval // Litopys UPA. Nova seriia. - T. 3: Borotba proty UPA i natsionalistychnoho pidpillia: dyrektyvni dokumenty TsK Kompartii Ukrainy. 1943 - 1959. - Kyiv-Toronto, 2001. - S. 9-40.

Стаття надійшла до редакиії 12.03.2017 p. 